\title{
Pengaruh Penyaluran Dana ZIS dan Tingkat Inflasi terhadap Pertumbuhan Ekonomi Indonesia Periode 2011-2015
}

\author{
Rachmasari Anggraini, Ryval Ababil, Tika Widiastuti \\ Program Studi Magister Ekonomi Islam, \\ Sekolah Pascasarjana, Universitas Airlangga \\ Email: rachmasarianggraini@yahoo.com
}

\begin{abstract}
This study aims to analyze the influence of ZIS fund's and inflation towards the economic growth in Indonesia during 2011-2015. The research method is quantitative method with multiple linear regression technique. The data used is the collected secondary data of remittances of ZIS from BAZNAS (national amil zakat agency) and inflation rate of BI (Bank of Indonesia) in Indonesia during 2011-2015 that includes monthly data all over Indonesia. The results of the research indicates that the funds of ZIS (X1) affects positively and significantly towards Indonesia's economic growth and inflation (X2) do not affect significantly to economic growth in Indonesia as well as ZIS fund and the inflation simultaneously affected the economic growth significantly during 2011-2015 in Indonesia.
\end{abstract}

Keywords: ZIS fund, inflation, economic growth 


\begin{abstract}
ABSTRAK
Penelitian ini ditujukan untuk menganalisis mengenai pengaruh dana ZIS dan inflasi terhadap Pertumbuhan Ekonomi di Indonesia periode 2011-2015. Metode penelitian yang digunakan adalah metode kuantitatif dengan teknik regresi linier berganda. Data yang digunakan adalah data sekunder dengan mengumpulkan data penyaluran dana ZIS dari BAZNAS (badan amil zakat nasional) dan data tingkat inflasi dari BI (bank indonesia) di Indonesia periode 2011-2015 yang mencakup data bulanan seluruh Indonesia. Hasil penelitian yang dilakukan menunjukkan bahwa dana ZIS (X1) berpengaruh positif dan signifikan terhadap pertumbuhan ekonomi di Indonesia dan inflasi (X2) tidak berpengaruh signifikan terhadap pertumbuhan ekonomi di Indonesia serta dana ZIS dan inflasi secara simultan berpengaruh signifikan terhadap pertumbuhan ekonomi di Indonesia periode 20112015.
\end{abstract}

Kata kunci: Dana ZIS, Inflasi, Pertumbuhan Ekonomi

\title{
1. Pendahuluan
}

Setiap Negara pasti mempunyai tujuan dalam pembangunan ekonomi termasuk Indonesia. Menurut Irawan dan Suparmoko (1992) dalam Haryanto (2013:149), pembangunan ekonomi adalah usaha-usaha untuk meningkatkan taraf hidup suku bangsa yang seringkali diukur dengan tinggi rendahnya pendapatan riil per kapita. Secara umum pembangunan ekonomi juga bertujuan untuk mencapai pertumbuhan ekonomi yang cukup tinggi, menjaga keseimbangan ekonomi negara dan pendistribusian pendapatan yang merata. Pertumbuhan ekonomi merupakan salah satu tolok ukur dari keberhasilan pebangunan ekonomi.

Tabel 1.1.:

Perumbuhan Ekonomi dan Inflasi di Indonesia Periode 2011-2015.

\begin{tabular}{|c|c|c|}
\hline Tahun & $\begin{array}{c}\text { Laju Pertumbuhan Ekonomi } \\
(\mathbf{\%})\end{array}$ & Inflasi (\%) \\
\hline 2011 & 6,17 & 3,79 \\
\hline 2012 & 6,03 & 4,3 \\
\hline 2013 & 5,56 & 8,38 \\
\hline 2014 & 5,39 & 8,36 \\
\hline 2015 & 4,23 & 3,35 \\
\hline
\end{tabular}

Sumber: Badan Pusat Statistik (BPS)

Vol. 3, No.2, Agustus 2018 
Dapat dilihat pada Tabel 1.1 Dipaparkan laju pertumbuhan ekonomi periode 2011-2015. Tabel dibawah ini menunjukkan bahwa perkembangan pertumbuhan ekonomi di Indonesia selama tahun 2011-2015 ini selalu menurun, penurunan pertumbuhan ekonomi di Indonesia ini disebabkan oleh perekonomian global yang mengalami pelemahan, sedang terjadi krisis ekonomi global yang berdampak terhadap pertumbuhan ekonomi di Indonesia.

Terdapat beberapa faktor yang mempengaruhi pencapaian pertumbuhan ekonomi di suatu Negara, menurut Silva, Engla Desnim (2013: 224), salah satu indikator ekonomi makro yang digunakan untuk melihat atau mengukur stabilitas perekonomian suatu negara adalah inflasi. Perubahan dalam indikator ini akan berdampak terhadap dinamika pertumbuhan ekonomi. Dalam perspektif ekonomi, inflasi merupakan fenomena moneter dalam suatu negara dimana naik turunnya inflasi cenderung mengakibatkan terjadinya gejolak ekonomi. Naik turunnya inflasi dapat dilihat pada Tabel 1.1.

Disamping itu, dalam perspektif ekonomi Islam juga terdapat faktor yang mempengaruhi pertumbuhan ekonomi yaitu penyaluran dana zakat, infak dan sedekah (ZIS). Penyaluran dana ZIS ini sebagai pendorong pertumbuhan ekonomi, menurut Riyandono (2008: 54), dalam Islam diwajibkan untuk mengeluarkan zakat, yang memiliki fungsi untuk memaksa seseorang untuk menjadikan hartanya agar senantiasa produktif atau selalu berputar. Dengan harta yang selalu produktif ini maka akan meningkatkan output (perkembangan dan pertumbuhan ekonomi), penyerapatan tenaga kerja, pendapatan dan kesejahteraan masyarakat dan lain sebagainya. Dapat dilihat pada Tabel 1.2. berikut,

Tabel 1.2.: Penyaluran ZIS pada BAZNAS periode 2011-2015

\begin{tabular}{|c|c|c|}
\hline Tahun & Penyaluran dana ZIS & $\mathbf{( \% )}$ \\
\hline 2011 & $39.804 .731 .212,00$ & $19,4 \%$ \\
\hline 2012 & $38.513 .551 .378,00$ & $18,8 \%$ \\
\hline 2013 & $44.363 .070 .093,00$ & $21,6 \%$ \\
\hline 2014 & $55.990 .121 .023,00$ & $27,2 \%$ \\
\hline 2015 & $26.500 .542 .731,00$ & $12,9 \%$ \\
\hline
\end{tabular}

Sumber: Badan Amil Zakat Nasional (BAZNAS)

Semakin meningkatnya penyaluran dana ZIS maka dapat mendorong pertumbuhan ekonomi di Indonesia, begitupula dengan terjadinya inflasi di Indonesia maka akan meningkatkan harga barang dan jasa serta menurunkan produksi dan menurunkan tingkat konsumsi masyarakat, dengan seperti itu maka inflasi akan menurunkan pertumbuhan ekonomi. Kebijakan pemerintah adalah bagaimana cara untuk mencegah terjadinya inflasi yang terlalu tinggi supaya tetap stabil dan dapat menunjang pertumbuhan ekonomi di Indonesia, maka dari penelitian ini bertujuan untuk melihat Pengaruh Dana Zakat, Infaq, Shodaqoh 
(ZIS), dan Inflasi Terhadap Pertumbuhan Ekonomi di Indonesia Periode 20112015 .

\section{Landasan Teori}

\subsection{Teori Pengelolaan Zakat}

Berdasarkan Undang-undang Republik Indonesia Nomor 23 tahun 2011 tentang Pengelolaan Zakat pasal 1 ayat 2, definisi zakat adalah harta yang wajib dikeluarkan oleh seorang muslim atau badan usaha untuk diberikan kepada yang berhak menerimanya sesuai dengan syariat Islam. Menurut Riyandono (2008: 23), berhak menerimanya sesuai dengan syariat Islam. Menurut Riyandono (2008: 2-3) kata zakat dalam bentuk ma'rifah (definisi) disebut sebanyak 30 kali di dalam Al-qur'an, diantara 27 kali disebutkan dalam 1 ayat bersama sholat, dan hanya 1 kali disebutkan dalam konteks yang sama dengan sholat tetapi tidak di dalam 1 ayat. Apabila diperiksa ketiga puluh kali zakat disebutkan itu delapan terdapat di dalam surat-surat yang turun di makkah dan selebihnya di dalam suratsurat yang turun di madinah. Perintah zakat dan sekaligus mendefinisikan zakat antara lain disebutkan, dalam (QS. Al-Baqarah: 43); (QS. At-Taubah: 103); (QS. Adzaariyat: 19).

Pasal 1 ayat 3 terdapat pengertian infak. Infak adalah harta yang dikeluarkan oleh seseorang atau badan usaha diluar zakat untuk kemaslahatan umat. Pada pasal 1 ayat 4, sedekah adalah harta atau nonharta yang dikeluarkan oleh seseorang atau badan usaha diluar zakat untuk kemaslahatan umat. Menurut Hafidhuddin (1998: 15) sedekah berasal dari kata shadaqa yang berarti 'benar' orang yang suka bersedekah adalah orang yang benar pengakuan imannya. Menurut terminologi syariat, pengertian sedekah sama dengan pengertian infak, termasuk juga hukum dan ketentu-ketentuannya. Hanya saja, jika infak berkaitan dengan materi, sedangkan sedekah memiliki arti lebih luas, menyangkut hal yang bersifat nonmateriil.

\subsection{Teori Inflasi}

Menurut Djohanputro (2006: 147) Inflasi didefinisikan sebagai kecenderungan kenaikan harga secara umum yang bersifat terus-menerus. Inflasi dapat dihitung berdasarkan penghitungan sekelompok barang dan jasa yang dikonsumsi oleh sebagian besar masyarakat. Menurut Naf'an (2014:111) Inflasi diukur dengan tingkat inflasi (rate of inflation) yaitu tingkat perubahan dari tingkat harga secara umum. Dapat dituliskan dengan persamaan sebagai berikut:

Rate of inflation $=\frac{\text { tingkat harga } \mathrm{t}-\text { tingkat harga } \mathrm{t}-1}{\text { Tingkat harga } \mathrm{t}-1} \times 100$

Konsep Inflasi Perspektif Islam, menurut Naf'an (2014:114) Islam tidak mengenal istilah inflasi, karena mata uangnya stabil dengan digunakannya mata uang dinar dan dirham. 


\subsection{Teori Pertumbuhan Ekonomi}

Pertumbuhan Ekonomi dapat dihitung menggunakan PDB riil, Menurut Raharja dan Manurung (2001: 178) Nilai PDB riil seringkali digunakan untuk mengukur pertumbuhan ekonomi, yaitu nilai PDB yang dihitung berdasarkan harga konstan. Cara: Growth $(\%)=\frac{\text { PDB riilt-PDB riilt-1 }}{\text { PDB riilt-1 }}$

Pertumbuhan Ekonomi Perspektif Islam Menurut Ahmad (1997) dalam Naf'an (2014: 238) dalam pertumbuhan ekonomi perspektif Islam, pertumbuhan dan pembangunan dalam ekonomi islam ditekanan pada perhatian yang sangat serius pada pengembangan sumberdaya manusia, tidak hanya diwujudkan dalam keberhasilan pemenuhan kebutuhan material saja, namun juga kebutuhan dan persiapan menyogsong kehidupan akhirat.

Menurut Hafidhuddin (1998: 17) jika zakat dikelola (pengambilan dan pendistribusiannya) dengan baik dan benar, mampu menanggulangi atau paling tidak memperkecil kemiskinan dan kefakiran. Jalan keluar yang perlu dilakukan mengoptimalkan pengambilan dan pendistribusian zakat tentunya dengan meningkatkan kesungguhan dan profesionlisme kerja amil zakat (yayasan atau lembaga) sehingga menjadi amil yang amanah, jujur, adil, bertanggungjawab, serta mampu melaksanakan tugas keamilan dengan menyalurkan dana zis tepat sasaran kepada orang yang berhak menerimanya, dengan seperti itu pengelolaan zakat akan dapat meningkatkan pertumbuhan ekonomi melalui penyaluran dana zis tepat sasaran yang akan mengentaskan kemiskinan dan kefakiran.

Menurut Naf'an (2014: 126) inflasi yang tinggi tingkatnya tidak dapat menggalakkan perkembangan ekonomi. Biaya yang terus menerus naik menyebabkan kegiatan produktif sangat tidak menguntungkan. Maka pemilik modal biasanya lebih suka menggunakan uangnya untuk tujuan spekulasi. Antara lain tujuan ini dicapai dengan membeli harta-harta tetap seperti tanah, rumah dan bangunan, oleh karena pengusaha lebih suka menjalankan kegiatan investasi yang bersifat seperti ini, investasi produktif dapat berkurang dan tingkat kegiatan ekonomi akan menurun. Akibatnya lebih banyak pengangguran dan menurunkan pertumbuhan ekonomi.

\section{Metode Penelitian}

Pendekatan yang digunakan dalam penelitian ini adalah pendekatan kuantitatif dengan metode regresi linier berganda yang diolah menggunakan software SPSS. Dalam penelitian ini data-data yang digunakan adalah data sekunder. Data yang akan dipergunakan ialah data time series bulanan dari tahun 2010-2015. Data yang dibutuhkan; pertama, data dana ZIS tahun 2011-2015 bersumber dari Badan Amil Zakat Nasional (pusat.baznas.go.id). kedua, data 
inflasi Indonesia tahun 2011-2015 bersumber dari BPS (www.bps.go.id). Ketiga, data pertumbuhan ekonomi Indonesia tahun 2011-2015 bersumber dari BPS (www.bps.go.id).

Selanjutnya, populasi yang digunakan dalam penelitian ini adalah seluruh lingkup Indonesia dalam kurun waktu lima tahun, yaitu tahun 2011-2015. Seluruh data yang digunakan berupa data bulanan, maka populasnya berjumlah 60 pengamatan. Teknik pengambilan sempel yang digunakan dalam penelitian ini adalah sampling jenuh. Sampling jenuh adalah teknik penentuan sampel apabila seluruh anggota populasi digunakan sebagai sampel (Anshori dan Iswati, 2009: 106). Teknik Analisis dan Pembahasan menggunakan uji asumsi klasik dan analisis regresi berganda.

\section{Hasil dan Pembahasan}

Berdasarkan penelitian yang telah dilakukan, berikut hasil pengujian Instrumen penelitian:

\subsection{Uji t Statistik}

Berdasarkan perhitungan $t$-statistic yang diperoleh adalah 2,939 > t tabel sebesar 2,00172. Dengan nilai signifikan sebesar 0,005 < $\alpha$ sebsesar 0,05 sehingga Ho ditolak. Jadi terdapat pengaruh ZIS terhadap pertumbuhan ekonomi di Indonesia periode 2011-2015. Berdasarkan perhitungan $t$-statistic yang diperoleh adalah sebesar 0,193 < t table sebesar 2,00172, dengan nilai signifikan sebesar $0,848>\alpha$ sebesar 0,05 maka Ho diterima. Jadi, tidak terdapat pengaruh inflasi terhadap pertumbuhan ekonomi di Indonesia periode 2011-2015.

Tabel 4.1.: Hasil Uji t

Coefficients $^{\mathrm{a}}$

\begin{tabular}{|c|c|c|c|c|c|}
\hline \multirow{2}{*}{ Model } & \multicolumn{2}{|c|}{$\begin{array}{c}\text { Unstandardized } \\
\text { Coefficients }\end{array}$} & $\begin{array}{c}\text { Standardized } \\
\text { Coefficients }\end{array}$ & \multirow{2}{*}{$\mathrm{t}$} & \multirow{2}{*}{ Sig. } \\
\cline { 2 - 4 } & $\mathrm{B}$ & Std. Error & Beta & & \\
\hline (Constant) & -1.318 & 1.083 & & -1.217 & .229 \\
ZIS & .144 & .049 & .390 & 2.939 & .005 \\
INFLASI & -.008 & .040 & -.026 & -.193 & .848 \\
\hline
\end{tabular}

Sumber : Data diolah, 2015

\subsection{Hasil Uji f Statistik}

Berdasarkan perhitungan $f$-statistic yang diperoleh adalah sebesar 5,543 > $\mathrm{f}$ table sebesar 4,00, dengan nilai p-value sebesar 0,007 < $\alpha$ sebesar 0,05 maka Ho ditolak. Jadi, terdapat pengaruh dana ZIS dan inflasi terhadap pertumbuhan ekonomi di Indonesia periode 2011-2015. 
Tabel 4.2.: Hasil Uji f Statistik

\begin{tabular}{|c|c|c|c|c|c|}
\hline Model & $\begin{array}{c}\text { Sum of } \\
\text { Squares }\end{array}$ & Df & $\begin{array}{c}\text { Mean } \\
\text { Square }\end{array}$ & F & Sig. \\
\hline Regression & .336 & 2 & .168 & 5.453 & $.007^{\mathrm{a}}$ \\
Residual & 1.755 & 57 & .031 & & \\
Total & 2.091 & 59 & & & \\
\hline
\end{tabular}

Sumber: Sumber : Data diolah, 2015

\subsection{Koefisien Determinasi}

Analisis koefisien determinasi digunakan untuk mengetahui seberapa jauh kemampuan persentase variable ZIS (X1) dan inflasi (X2) terhadap pertumbuhan ekonomi (Y). Nilai koefisien determinasi ditunjukan dengan nilai adjusted $\mathrm{R}$ Squared bukan R Squared, karena nilai R Squared bias, sedangkan nilai adjusted R-Squared dapat naik turun jika suatu variabel independen ditambahkan dalam model.

Tabel 4.3.: Hasil Koefisien Determinasi Model Summary

\begin{tabular}{|c|c|r|r|r|r|}
\hline Model & $\mathrm{R}$ & R Square & $\begin{array}{c}\text { Adjusted R } \\
\text { Square }\end{array}$ & $\begin{array}{c}\text { Std. Error of } \\
\text { the } \\
\text { Estimate }\end{array}$ & $\begin{array}{c}\text { Durbin- } \\
\text { Watson }\end{array}$ \\
\hline 1 & $.401^{\mathrm{a}}$ & .161 & .131 & .1754600 & .292 \\
\hline
\end{tabular}

Sumber : Data diolah, 2015

Berdasarkan Tabel diatas dapat dilihat bahwa koefisien determinasi atau nilai Adjusted R-Squared dari hasil regresi di atas yaitu 13,1\%. Hal ini berarti menjelaskan variasi variable dependen yaitu pertumbuhan ekonomi dapat dijelaskan oleh variable independen yaitu dana ZIS dan inflasi sebesar 13,1\%. Sedangkan sisanya yaitu $86.9 \%$ dijelaskan oleh variable lain yang tidak diteliti atau tidak dimasukkan dalam model penelitian ini.

\section{Analisis}

5.1. Pengaruh dana ZIS terhadap pertumbuhan ekonomi di Indonesia periode 2011-2015

Hasil penelitian ini menunjukkan bahwa dana ZIS (X1) berpengaruh positif dan signifikan terhadap pertumbuhan ekonomi di Indonesia periode 2011-2015. Hasil analisis dana ZIS sebesar 0,144 yang artinya apabila perubahan dana ZIS naik $1 \%$ maka terjadi perubahan pertumbuhan ekonomi akan bergerak kearah yang sama (naik) sebesar $14,4 \%$. 
Hasil dari penelitian ini sesuai dengan penelitian yang pernah dilakukan oleh Sarea (2012) menunjukkan bahwa peningkatan dana zakat memberikan kontribusi yang signifikan terhadap pertumbuhan ekonomi, zakat sebagai instrumen keuangan yang berdampak pada pertumbuhan ekonomi. Zakat sebagai kerangka kerja alternatif dalam ekonomi islam. Model alternatif zakat ini secara signifikan berkontribusi pada distribusi masyarakat. Kemudian pada penelitian Suprayitno, dkk (2009) juga menunjukkan bahwa pembagian zakat memiliki pengaruh positif dan signifikan terhadap pertumbuhan ekonomi. Dana zakat selain disalurkan untuk tujuan konsumsi dapat juga disalurkan untuk efek jangka panjang yang lebih efektif, yang memungkinkan penerima untuk mendapatkan pendapatan tetap dan diharapkan dapat beralih menjadi muzaki (Pembayar Zakat), seperti diberikan modal atau pelatihan.

5.2. Pengaruh inflasi terhadap pertumbuhan ekonomi di Indonesia periode 2011-2015

Hasil penelitian ini menunjukkan bahwa inflasi (X2) tidak berpengaruh signifikan terhadap pertumbuhan ekonomi di Indonesia periode 2011-2015. Hasil analisis inflasi sebesar 0,008 yang artinya apabila perubahan inflasi naik $1 \%$ maka terjadi perubahan pertumbuhan ekonomi akan bergerak kearah yang berbeda (turun) sebesar 0,8\%. Hasil penelitian ini konsisten dengan hasil penelitian yang diteliti oleh Khoirina Laiylana (2013) menunjukkan bahwa inflasi berpengaruh negatif terhadap pertumbuhan ekonomi di Indonesia. Tingginya inflasi akan direspon negatif oleh pertumbuhan ekonomi di Indonesia. Bank Indonesia menuliskan bahwa inflasi yang tinggi akan menyebabkan pendapatan riil masyarakat akan terus menurun sehingga standart hidup dari masyarakat juga turun. Hal ini akan mempengaruhi keputusan masyarakat melakukan konsumsi, investasi, dan produksi sehingga akan menurunkan pertumbuhan ekonomi. Penelitian ini juga sesuai dengan penelitian yang diteliti oleh Engla Desnim Silva dkk (2013) menunjukkan bahwa inflasi berpengaruh tidak signifikan terhadap pertumbuhan ekonomi di Indonesia. Hal ini disebabkan oleh harga produksi yang meningkat dapat menurunkan pertumbuhan ekonomi, karena masyarakat akan mengurangi permintaan mereka terhadap barang dan jasa. Sehingga, meskipun terjadi penurunan inflasi pada suatu periode, pertumbuhan ekonomi tidak langsung menunjukkan perubahan, kecuali jika inflasi mengalami penurunan secara tetap maka akan terlihat perubahan pada pertumbuhan ekonominya.

\subsection{Pengaruh dana ZIS dan inflasi terhadap pertumbuhan ekonomi di} Indonesia periode 2011-2015.

Hasil penelitian ini menunjukkan bahwa secara bersama-sama atau simultan dana ZIS (X1) dan inflasi (X2) berpengaruh signifikan terhadap pertumbuhan ekonomi di Indonesia periode 2011-2015. Hasil analisis regresi linier berganda menunjukkan nilai signifikan 0,007 yang artinya bahwa secara bersama-sama 
terdapat pengaruh yang signifikan dari variable independen (dana ZIS dan inflasi) terhadap pertumbuhan ekonomi di Indonesia periode 2011-2015. Hasil analisis dana ZIS sebesar 0,144 yang artinya apabila perubahan dana ZIS naik 1\% maka terjadi perubahan pertumbuhan ekonomi dan akan bergerak kearah yang sama (naik) sebesar 14,4\%. Kemudian untuk inflasi hasil analisis inflasi sebesar 0,008 yang artinya apabila perubahan inflasi naik $1 \%$ maka perubahan pertumbuhan ekonomi akan bergerak kearah yang berbeda (turun) sebesar $0,8 \%$.

\section{Kesimpulan}

Berdasarkan penelitian yang telah dilakukan maka dapat disimpulkan bahwa Varibel dana ZIS berpengaruh positif terhadap pertumbuhan ekonomi di Indonesia periode 2011-2015. Hal ini dikarenakan semakin tingginya penyaluran dana ZIS menandakan semakin tinggi pula tingkat pertumbuhan ekonomi masyarakat di Indonesia. Dana ZIS selain disalurkan untuk tujuan konsumsi, dapat juga disalurkan untuk efek jangka panjang yang lebih efektif, yang kemudian akan berdampak pada naiknya pendapatan para mustahik yang kemudain dimasa yang akan datang mereka akan menjadi muzaki (pembayar zakat), dengan semakin meratanya distribusi dana ZIS maka akan dapat mendorong dan mengendalikan laju pertumbuhan ekonomi di Indonesia. Pada variabel inflasi, variabel ini tidak berpengaruh terhadap pertumbuhan ekonomi di Indonesia periode 2011-2015. Tingkat inflasi di Indonesia yang tinggi mengakibatkan rendahnya pertumbuhan ekonomi di Indonesia, disebabkan oleh harga produksi yang meningkat dan meningkatkan harga barang dan jasa, dengan seperti itu masyarakat akan mengurangi permintaan mereka terhadap barang dan jasa, yang kemudian akan berpengaruh terhadap menurunnya pertumbuhan ekonomi di Indonesia. Selain itu, variabel dana ZIS dan inflasi berpengaruh secara bersama-sama atau simultan terhadap pertumbuhan ekonomi di Indonesia periode 2011-2015. 


\section{Daftar Pustaka}

Al-Qur'an, diambil dari Software Qur'an in Word

Ghozali, I. 2001. Aplikasi Analisis Multivariate dengan Program SPSS. Semarang: Universitas Diponegoro. . 2006. Aplikaasi Analisi Multivariate Menggunakan SPSS. Semarang: Universitas Diponegoro . 2013. Aplikasi Analisis Multivariate dengan Program IBM SPSS 21. Edisi 7. Semarang: Universitas Diponegoro.

Hafidhuddin, D. 1998. Tentang Zakat, Infak, Sedekah. Jakarta: Gema Insani.

Lailyan, K. 2013. Pengaruh Tingkat Pengangguran, Tingkat Inflasi, dan ertumbuhan Jumlah Uang Beredar, terhdap Pertumbuhan Ekonomi di Indonesia Periode 1974-2011. Skripsi. Surabaya: Fakultas Ekonomi dan Bisnis Universitas Airlangga

Naf'an. 2014. Ekonomi Makro Tinjauan Ekonomi Syari'ah.Yogyakarta: Graha Ilmu.

Raharja \& Manurung. 2004. Teori Ekonomi Mikro: Suatu Pengantar. Jakarta: Lembaga Penerbit Fakultas Ekonomi Universitas Indonesia.

Republik Indonesia. Undang-undang Republik Indonesia Nomor 23 Tahun 1999 Tentang Pengelolaan Zakat. 1999. Jakarta: Republik Indonesia.

Ryandono, M.N. 2008. Ekonomi ZISWAQ (zakat,infak,shodaqoh dan wakaf). Surabaya: IFDI dan Cenforis.

Santoso, S. 2015. Menguasai Statistik Parametrik. Jakarta :PT Alex Media Komputindo.

Sarea, A. 2012. Zakat as a Benchmark to Evaluate Economic Growth : an Alternative Approach. Vol 3 (18) : 242-245.

Silva, Wardi, Aimon. 2013. Analisis Pertumbuhan Ekonomi, Investasi, daan Inflasi di Indonesia. Vol. 1 (2)

Syaikho, Asy'ari. 2012. Pengelolaan Zakat, Infak, Sedekah dalam Upaya Mengubah Status Mustahiq menjadi Muzzaki.Skripsi. Semarang: Institusi Agama Islam Negeri Walisonggo.

Eko, Kader, Harun. 2013. The Impact of Zakat on Aggregate Consumtion in Malaysia. Vol 9 (1): 59-60

www.pusat.baznas.go.id

www.bps.go.id 